\title{
2 Infrastructures of imagination
}

One often forgets that the poet pays court to his fellow experts more than to anyone else.

Abdelfattah Kilito, The Author and His Doubles

In the story that Alshimaa Hamed told of her literary becoming in Chapter 1, her writing and her career as a writer gained their shape through encounters, friendships, readings, institutions, and social circles. Literature in this sense is not only ultimately social, but it is also a material practice that is grounded in infrastructures and political economy. Books were available during her childhood because her family and friends of her family had experienced higher education, and she in turn was encouraged to attend university. A degree of material comfort enabled Alshimaa and her young female friends to gather at her house to read and discuss, and later the cafés near her university allowed gatherings outside the family home. Forms of living and socialising that were common in her social class allowed her to dedicate time to reading and writing. Public-sector and private publishing and distribution made books easily available, and this, in time, allowed Alshimaa to search for a suitable publisher for her works. Some venues - such as public-sector cultural centres - were too restrictive for her, but she embraced others - such as the funding and networks provided by al-Mawrid - to enable her literary career. In addition, as Alshimaa grew up, online communication became an increasingly important part of the infrastructure of literary imagination.

The necessity of such an infrastructure is largely shared among all writers we know. Books, be they printed or electronic, are an indispensable part of their literary careers. While the spoken word remains an important element, especially of colloquial poetry, all the authors we met recorded their works in writing, and read others' writings. Publication is a widely shared criterion of being recognised as a writer, and the printed book is the form of publication with the greatest prestige, even at a time when young people increasingly read and write via their phones and laptops. Encountering others, and both supporting and being supported, appear to be indispensable. At the same time, however, different writers seek to access distinct infrastructures and social groups. Just as Alshimaa moved from one circle to another as she travelled her path of literary becoming, others move in some circles and not others, are able to access some means of publication but not others, read some books but not others, compete for some sources of symbolic and economic capital but not others. At the same time, they subscribe to some ideas of authorship rather than others, and strive towards one set of literary aes- 
thetics rather than another. Imagination has a political economy, and different infrastructures resonate with different imaginaries.

How do such infrastructures contribute to the making of literary careers, sociality, and aesthetics? This question became increasingly pertinent in the course of our fieldwork. In this chapter, we attempt a partial answer to the question by describing some locations of literary sociality in Alexandria during the 2010s. Literature as a social institution, we argue, takes place primarily and foremost in milieus of like-minded people who encourage each other in a certain direction.

Between autumn 2014 and spring 2015, Mukhtar - on occasion accompanied by Samuli - regularly attended meetings in four literary spaces: the Alexandria branch of the Writers' Union of Egypt, a debating group called Mukhtabar alSardiyat (Narratives Laboratory) at the Alexandria Library, symposia at the El Cabina cultural space, which was run by an independent cultural association, and a writing workshop at Fabrica, a self-funded venue. It was a time of heavyhanded political clampdown on anything that resembled political opposition, and independent cultural spaces that often relied on international funding were also beginning to feel the pressure. Literary and cultural circles were still flourishing, but the cultural boom that had begun in 2011 was coming to an end. Two years later, both Fabrica and El Cabina had closed their doors.

As a novelist who had been born and brought up in a village and worked as a teacher in Alexandria, Mukhtar's literary trajectory had taken him from more accessible but in aesthetic terms more conservative circles, similar to the Writers' Union, towards more experimental but less accessible circles, which included El Cabina and Fabrica among their meeting places. He did not feel quite at home in either, however.

Mukhtar felt that the globally connected scene of downtown Alexandria, while open to the world and new ideas, was busy drawing visible and invisible social borders around itself. The scene was organised to a large extent around 'independent' (that is, independent from the Ministry of Culture) cultural institutions that relied on international and private funding, and its aesthetics followed global developments more closely. This was the cultural scene that foreign researchers and students living in and visiting Alexandria were most likely to know. Writers active in this scene were often internationally connected, and some of them had travelled abroad to residencies and literary festivals. Innovative genres such as the prose poem (qasidat al-nathr, see Chapter 8) and the graphic novel had been welcomed and developed in this scene. ${ }^{1}$ Socially controversial texts

1 While caricatures and comics have a long history in Egypt (Sherif 2015), the graphic novel (riwaya musawwara) is a recent genre. Metro by Magdy El Shafee $(2012,2013)$ is usually described 
(such as sexually explicit narration and unorthodox or irreverent takes on religion) were well represented in the symposia and workshops of this milieu, as were international theoretical debates. Some events and places that Mukhtar attended seemed connected with the wider world more closely than they were with some parts of Alexandria and Egypt.

This resulted in a class difference that Mukhtar, the son of a fisherman, sharply felt, although over the years he had successfully adopted a similar habitus. In intellectual and literary terms, he found these circles inspiring. They encouraged experimentation in style and themes, and in critical reflection, while few social and cultural taboos were recognised. Without regular contact with these circles, Mukhtar's own writing might have remained constrained by the conservative aesthetics of more provincial literary circles. But he was puzzled. To be open towards new ideas and aesthetics, was it really necessary to be socially exclusive at the same time?

In contrast, another regular site of our fieldwork was similar to the circles where Mukhtar's literary socialisation had begun. But also there, he no longer felt quite at home. At the Writers' Union, authors who were mostly past middle age cultivated the art of the laudatory speech, and celebrated each other as great poets and authors. Many of the independent circles were busy with critical exploration, questioning and pushing literary aesthetics a step further. The Writers' Union was comparably more committed to a canonised version of twentiethcentury Egyptian modernism, where authenticity, progress, and national liberation are expected to go hand in hand, and artists and writers are imagined to act as a top-down 'conscience of the nation' (see Armbrust 1996; Jaquemond 2008). Testing the limits was less encouraged. The prose poem genre that was well established in the Downtown scene caused heated debates among regulars at the Writers' Union. While themes of writing presented at the Union varied from subjective to socially critical to patriotic, and narrative approaches from subtle to straightforward, 'offensive words' (that is, sexually explicit language) were explicitly unwelcome at the meetings.

Inspired by one scene but troubled by its tendency towards social closure, and having a good time in the other but uninspired by its tendency towards aesthetic closure, Mukhtar addressed this dilemma with Samuli, and we began to think more systematically about literary sociality.

as the first Egyptian graphic novel. It was first published but immediately banned in 2010, and had its second Arabic edition in 2013. In a matter of five years, a small but innovative scene of authors and publishers of graphic novels emerged. Fabrica, where we did much of our fieldwork in 2014-2015, was among the first publishers of graphic novels in Egypt. 
The most immediate and tangible level of sociality is what we call circles, the specific cultural and literary gatherings of like-minded people, often combining friendship and shared interests, and constantly in a process of fragmentation and formation. Any given author is likely to move in several circles but be more at home in some than in others. Circles can take the shape of regular gatherings, networks, formal literary groups (gama'a adabiya), and of the shilla, 'clique' (de Koning 2009; Morsi 2009; Kreil 2012: 113-115), a more or less closed group of friends who gather frequently and often encourage and assist each other in their professional and other pursuits. Circles typically come together and share in what we call scenes: assemblages of physical and virtual sites where cultural production is made possible and is encouraged: cultural centres, art spaces, cafés, organisations, online groups and platforms.

At a higher level of abstraction, we speak of the milieu: the wider social location that includes not just the literary space but also political and religious stances, generational experience, and the class socialisation of those involved. A milieu in this sense is neither a clearly marked social structure nor a continuous tradition. Rather, it is something like a sociological reading of the phenomenological notion of the lifeworld (or, alternatively, an existentialist reading of Bourdieu's concepts of habitus and social field): the coming together of specific formative contexts, traditions, powers, and materialities in intersubjective experience.

All these levels of sociality are to some sense exclusionary, and are defined against each other as well as against the wider social mainstream. This is reflected in the terms used. In the colloquial Egyptian parlance of the urban bourgeoisie, ${ }^{2}$ the wider mainstream against which one searches for distinction

2 Today, the term middle class is used to describe so many different social strata and groups that we find it no longer helpful to locate people socially (although it does remain useful as a way to understand social aspiration, see Schielke 2012b). Poor people with higher education but few material means may see themselves as middle class, and so may rich and powerful people, including judges, military officers, and businesspeople. In Egypt, the English term middle class or upper middle class is commonly used to describe people who clearly stand above the middle income strata: they live in affluent neighbourhoods of major cities, have superior educational and economic capital, and come from families that earn their living in well-incomed positions in the public sector, white-collar positions in the private sector, business, and free professions - that is, people who in an older social scientific parlance would have been called the bourgeoisie. For the sake of clarity, we therefore speak of bourgeoisie to describe people from the above-described social stratum, and of the cosmopolitan class to refer to a sub-section of the bourgeois class who (or whose children) have been educated at international schools or abroad, and have the resources to participate in global forms of popular and consumer culture, including language and forms of socialisation. The cosmopolitan class includes the wealthiest 2 per cent (corresponding with the proportion of international schools, the most expensive category of education in Egypt), but also 
is called al-bi' $a$, 'the environment'. ${ }^{3}$ But bi' $a$ also means social milieu, and this was the term Mukhtar used in his first conceptual sketch of literary milieus in Alexandria. Another Arabic term that could be translated with the word 'milieu' is more commonly used by writers themselves: al-wasat, literally 'the middle', 'the scene', or 'the milieu', specifically al-wasat al-adabi, the literary scene or milieu. Writers who frequent a specific scene regularly refer to it as the scene, which reflects the naturalisation of each scene's claim to represent good, proper literature. In colloquial use, bi' $^{\prime}$ is usually a term of exclusion, while wasat more likely involves claims to belonging or insider status. By using circle, scene, and milieu in English to respectively describe literary sociality, its material conditions, and its location in a wider context, we intentionally cross the semantic difference between $b^{\prime} a$ and wasat. Sociality carries the duality of inclusion and mutual support, and exclusion and rejection of others. My wasat may be your bi'a.

\section{The formation of scenes}

Egyptian literature of the twentieth century posited an image of the author who is on the one hand a romantic genius producing from his or her authentic experience and inspiration, and on the other hand a committed citizen acting as a 'conscience of the nation' and as part of an 'army of the letters' (Jacquemond 2008: 18). During the early twenty-first century, this aspirational unity of aesthetic autonomy and nationalist commitment has increasingly been eroded (El Dabh 2016). It was never uncontested in Egypt, and different understandings of the role of the writer and the meaning and purpose of literature have competed for a long time (Jacquemond 2008). But the turn of the millennium witnessed growing splits within the literary landscape, which has become structured by three main poles: public-sector institutions and authors committed to a rather conservative version of twentieth-century modernist aspirations; a so-called independent cultural scene marked by more experimental and cosmopolitan aesthetics; and a thriving and increasingly professionalised market of best-selling fiction, selfhelp, and colloquial poetry.

people who through diasporic or migratory histories have access to certain forms of a cosmopolitan habitus without a correspondingly high income or status.

3 As one part of a logic of distinction that defines cosmopolitan bourgeois or 'upper-middle' classes in contradistinction against things and people that are sha 'bi ('popular'), bi' $a$ ('popular milieu'), baladi ('rural/local'), or local (used as an English loan word in Arabic) (Lagrange 2020: 27-32). 
These splits are far from absolute, of course, and on closer examination it becomes evident that the literary landscape is made of a large number of small circles of friends, institutions with their usual crowds, and regular meeting places, all of which are in a constant process of fragmentation and rearrangement. But there are tangible polarising tendencies that correspond in a complex way with generational experience, class, political positioning, and other lines of division. These have been further magnified in the aftermath of 2011.

The tensions described here are not entirely new: they are partly inherent to the historical formation of contemporary Arabic literature. While literature in a wider sense of stories and poems is as old as the Arabic language, literature as an autonomous social field akin to the French and English senses of littérature/ literature was established in Egypt in the late nineteenth and early twentieth centuries, in a process that built on but also transformed the older Arabic tradition of $a d a b$. Until then, $a d a b$ had meant the command of refined manners and morals, as well as their transmission and teaching by means of stories, poems, and scholarship. Some scholars, notably Michael Allan (2016), have argued that the redefinition of $a d a b$ as an equivalent of litterature in the early twentieth century involved a fundamental secularisation and silencing of the older tradition. Others, notably Teresa Pepe (2019b; see also Kesrouany 2019), argue that classical understandings were not silenced but rather absorbed into a reshaped understanding of modern Arabic adab/literature. She identifies three key conflicts that can be documented since the late nineteenth and early twentieth centuries and remain central today:

- an elitist claim to provide critique and guidance towards proper use of language and correct understanding of matters of importance, in contrast to a thriving market of popular literature, which has often been looked down upon by authors who consider themselves the critics/gatekeepers of fine expression and proper conduct;

- a moralist understanding of $a d a b$ as the learning of good manners and ethics, and a correspondingly pedagogical equation of socially conservative ethics and aesthetics, in contrast to tendencies towards artistic licence to provoke and break taboos; and

- an ideal of societal political engagement that educates the public, in contrast to tendencies to produce autonomous literary text and to raise questions rather than give answers.

From the 1950s until the 1990s, these different tendencies largely existed in one literary field that was dominated by the Egyptian state (Jacquemond 2008: 197). Commercial literature was often set apart by its circulation in cheap pocketbook series such as Rajul al-mustahil (Man of the impossible), a highly popular series 
of action adventures by Nabil Farouk, which was published in 160 issues between 1984 and 2009 (Bawardi and Faranesh 2018); it was often mentioned to us as an early inspiration and reading experience by writers from several generations. Since the turn of the millennium, the rise and diversification of independent commercial publishing, the involvement of internationally funded non-governmental organisations (NGOs) in cultural production at around the same time (commonly referred to as 'NGO-isation'), and the rise of online streaming platforms in the 2000s (since then, the main medium of colloquial poetry) have provided infrastructures that, at least temporarily, have made it possible for different ends of this productive field of tension to become increasingly separate as scenes or milieus of their own.

Such diversity has become an established feature of publishing. Egypt has a vast landscape of public-sector publishers as a heritage of the Nasserist socialist period, with the most important among them being the Egyptian General Book Organisation: this commands a large infrastructure and distribution network, but also suffers from long backlogs of titles waiting to be published and varying quality. Many other public-sector outlets have great problems with distribution, and some writers we met told us they have seen entire print runs stored and never sold because of bureaucratic hurdles. In the wake of the liberalisation of the Egyptian economy since the 1970s, private publishers have gradually grown from a lowbrow competitor of prestigious public-sector presses to the dominant site for both high-end and large-audience publishing. ${ }^{4}$

When he was interviewed by Samuli in 2020, the novelist Mohamed Rabie from Cairo, who has worked as a literary editor for two high-end publishers, pointed out that private publishing has become increasingly professional and diverse in the past decade, with a number of publishers specialising in the production of commercial bestsellers in genres such as horror, detective stories, and self-help, while others seek and fewer gain recognition as high-end literary and non-fiction publishers. Only a few private presses have professional marketing and distribution, and even fewer are committed to the additional expenditure of a literary editor - a role that is still an exception in Egyptian publishing, and in Rabie's view the key mark of high quality for publishers who aim for what he calls 'big-time readers' who can afford to buy good books on a regular basis and care about quality.

4 Translation is an important exception because it requires significant funds in foreign currency: these are available to a number of leading public-sector presses and to high-end private publishers - which are able to acquire translation funds from abroad. 
The vast majority of private publishers, however, make most of their revenue not from sales but from publishing fees. Often deprecatingly called 'stairwell publishers', indicating their lack of professionalism and infrastructure, small private publishers have proliferated, and they make it possible for anyone who has at their disposal the capital of 5,000 to 10,000 Egyptian pounds (in 2020 prices equalling about 275 to 550 euros) to publish a book that will probably have little to no distribution. This results in an extensive output of titles that are often full of mistakes, lack quality, and soon disappear into obscurity.

However, the division between professional and vanity publishers is far from clear, because publishers with a good standing sometimes publish books in exchange for fees, and many new publishers enter the market with the aim of generating revenue through sales, but fail to distribute their titles successfully. According to the novelist Nael Eltoukhy (2019), paying to publish is not necessarily a marker of low quality, but can be a stage in one's career. He had to pay to publish his first two books, and when he eventually received a contract where he was paid by the publisher instead of paying himself, he considered it a mark of being recognised as an accomplished author.

In all cases, selling books produced by their original publishers is only one channel among others for the distribution of literature. Piracy proliferates. Almost any successful book can be downloaded as a pdf document, and bestsellers are sold in bootleg prints on popular book markets. Outside the small landscape of professional publishers who make money by sales, the main means of distribution is authors themselves, handing out copies of their books as gifts for friends and peers, and to potentially important critics and translators. We always returned from symposia with a signed book or two.

Printed books remain a crucial status symbol of authorship across the literary spectrum, while at the same time younger Egyptians especially are reading and writing mainly via electronic media. Various online media (blogs and forums pioneering the field in the 2000s, and online news and publishing outlets, social media, and streaming platforms dominating throughout the 2010s) have provided flourishing and often transient platforms for literary publishing, reading, and debate. In contrast, most printed books only find a handful of readers, and it takes no talent to publish a book. And yet the material shape of the printed book - preferably accompanied by a handwritten dedication - carries an unbroken status. A book marks a person as an intellectual in the tradition of Egyptian modernism since the colonial era (Jacquemond 2008). And for all those who fail 
to find a high-end venue for their manuscripts, ${ }^{5}$ 'stairwell publishers' make it possible to buy that status.

The proliferation of private publishing and the rise of online media coincided with the internationally funded NGO-isation of parts of the cultural scene in the early 2000s. This has enabled the establishment and continuity of numerous independent cultural spaces, programmes and events, magazines and book series, and translations. This has been a contested process. Paranoid accusations of treason and of serving foreign interests have escalated since 2011. On a less paranoid note, writers not included in international circuits have questioned the literary merit of those who are. We have also encountered people working in independent institutions who have complained about funder bias, expressing their annoyance about international visitors and institutions trying to impose their interests and concerns on their Egyptian partners (see also Elnozahy 2020). This difficult relationship became the topic of a project that Daniela Swarowsky curated with Samuli, Maher Sherif, Aliaa Elgready, Ahmed Salem, and a group of writers (many of whom also are featured in this book), which resulted in the art exhibition In Search of Europe? in 2013 (Swarowsky et al. 2013). One of the absurdities we addressed in that project was that we were inviting Alexandrian artists and writers to participate in a critical discussion of the relationship with foreign funders - with funding from Germany and for a project curated and located in that country. And yet literature has faced the least pressure to comply with funder bias during the period of our research, thanks to the language barrier: most international partners and visitors simply did not know enough Arabic to impose their bias. Where funding institutions were involved in a selective or curating capacity in the literary field, such as al-Mawrid supporting two of Alshimaa Hamed's books, this work was done by Egyptian critics close to the cosmopolitan avantgarde and not by foreign visitors.

Initially, NGO-isation appeared to fit well into the Mubarak regime's combination of authoritarian rule with international investment and showcase pluralism. However, the 25 January revolution of 2011 showed that this was not the whole story. Between 2011 and 2013, Egypt witnessed a veritable cultural boom. Independent spaces mushroomed, most of them short lived. Concerts, lectures, and workshops were numerous and well attended, although funding was already scarcer than it had been before 2011, as political pressure against internationally funded organisations grew and 'foreign funding' became a paranoid accusation

5 Mohamed Rabie said that as a literary editor he would receive between one and two hundred submissions in a year, most of them of extremely poor quality, and only a couple of them would be published by the presses he worked for. 
of treason. From summer 2013, when the military seized back power from the Muslim Brotherhood, the space for independent organisations became increasingly narrow, and it soon became evident that the new regime considered all kinds of social and cultural initiatives as potential agents of insurrection. Restrictive legislation and other measures against internationally funded NGOs in 2017, followed by a dramatic grab for control by state-aligned syndicates of artists, musicians, actors, and film-makers 2019, destroyed most of the briefly flourishing scene of independent initiatives (Anonymous 2020; El Tarzi 2020; Elnozahy 2020). However, the greater plurality of literary scenes and milieus that has emerged since the 1990s for the time being remains a feature of the landscape.

\section{A provincial setting}

A paradoxical answer to the 'where' question about Alexandrian literature is that literature is in Cairo, and to a lesser degree in various centres of power abroad. The commercial power of publishing and bookselling is almost totally concentrated in Cairo. This is so taken for granted that when he heard the recording of the interview in which Samuli asked Mohamed Rabie in 2020 about why this is so, Mukhtar laughed: 'Are you seriously asking that question?' Rabie replied: 'If you told me there was a publishing house in Aswan, I'd find it very strange.' Egypt is an extremely centralised state, and much of its economic activity and cultural life follow the logic of the state's centralisation. This makes publishing in Alexandria commercially unviable owing to the lack of distribution networks, and the public and critical attention that are concentrated in the capital city. Kalima, a publishing house we followed in our fieldwork that published Mukhtar's second novel (Shehata 2013), closed its doors in 2015 after only three years of activity because of a lack of revenue and increasing costs. Fabrica, an art space and publishing house established in 2013, closed its doors as an art space in 2015 and as a publishing house two years later. The same fate has awaited most publishing initiatives we know of in Alexandria. A handful of private bookshops with a literary and intellectual focus have been able to stay in business (those that do so are located in the bourgeois neighbourhoods of Roshdy and Kafr Abdou), but their visibility is low compared with the thriving second-hand and bootleg book markets located in Nabi Danial Street and Raml Station in downtown Alexandria.

From the point of view of young people (especially women) with cultural ambitions and a sufficient degree of bourgeois and cosmopolitan capital to pursue those ambitions, Alexandria often appears as a conservative and gloomy city with many restrictions and few opportunities. There is a long-standing and ongoing 
brain drain from Alexandria to Cairo, and also abroad. Alexandrian writers who visit or work in Cairo describe it as a harsh and stressful city dominated by long working hours and dog-eat-dog competition, but at the same time it is the place where there are opportunities for work and income, where an intensity of networks and ideas can be found, and where there is more space for alternative ways of living. Few of those who leave for Cairo return. Another long-standing movement for work is towards the Arab Gulf states, which employ many Egyptians in the media and cultural sectors; some have gained powerful positions in publishing and cultural funding networks. Another international mobility current in the cultural sector consists of young and highly educated people, many among them formerly employed in NGOs or in freelance jobs in journalism or translation, who leave Egypt for Western Europe and North America mostly on student or freelance visas, or as refugees. ${ }^{6}$ This originally rather small current has been amplified in some of the circles we studied, largely because of the period of heavy political repression since 2013.

In contrast to the many currents of mobility from Alexandria abroad, the literary scenes in the city are overwhelmingly national. In the scenes we frequented, non-Egyptians were rare enough to stand out. Alexandria Library, international cultural centres, and some independent institutions regularly hosted international visitors, but few stayed longer than for a particular event. There is a lively if small Libyan intellectual exile scene in Alexandria. Writers we met included those with Palestinian, Sudanese, Syrian, Indonesian, and Finnish nationality: some had arrived recently, while others had been born and raised in Egypt but had no prospect of gaining Egyptian nationality. The difficulty of securing permanent residence in Egypt adds to the transience of non-Egyptians. For example, the Syrian poet Emad Al-Ahmad, who in a short time gained a name in the cosmopolitan-independent scene in Alexandria (e.g. Al-Ahmad 2014), had to leave for Turkey in 2015 because of issues with his residence status. He now lives in Malta.

Online media have to some extent softened, even transcended, the local and national focus of Alexandrian literary networks. Some writers who later gained a name in the internationally connected avant-garde initially became known through their blogs in the 2000s (see Jurkiewicz 2012; Pepe 2019a). In the 2010s, blogs were gradually marginalised by social media, most importantly Facebook, which since then has become a practically indispensable means of publicity

6 Trajectories of mobility are strongly structured by class, which forces many poorer people who travel for work to apply for asylum for the lack of other means to stay, while people with better resources can live abroad with a student or freelance status although they may have left Egypt for primarily political reasons. 
and communication, and is also often used for the publication and discussion of drafts. The limits of online communication and socialising are more fluid and usually less exclusive than, say, a gathering in a café. Online networks allow people who only rarely physically frequent cultural spaces to become at least partially involved in some of their activities. This has made communication across regional and national boundaries easier - and yet language, class, and ideological barriers have proved to be more persistent. And the tendency to fragmentation and the formation of smaller circles is shared by online and offline networks.

When opportunity arises, virtual networks also invite face-to-face encounters. Our very first fieldwork site in late 2010 and early 2011 was a regular gathering at a private bookshop that had emerged from the The Rewayat online forum inspired by Ahmed Khaled Towfik (1962-2018), a very influential and commercially successful writer of science fiction and horror. The forum had its peak of activity in the years before 2011, when it had a wide range of participants. The smaller circle of people who began meeting in person in Alexandria formed closer friendships and alliances, some of which continue by the time of writing this, in 2020.

Even in a time of mass emigration and online media, international connectedness remains a scarce resource in Alexandrian literary scenes. Travel and publication abroad and translation into foreign languages are therefore major sources of status. We assume that many of the writers who participated in our research did so partly because they hoped we would translate their work, although we kept telling people we are not translators. On one occasion, Samuli translated a colloquial poem into German for a research paper. Its author S., a poet well connected in Alexandria but not internationally, was very happy about the translation and asked Samuli to make a voice recording of it, which he did. S. circulated the translation on social media and received numerous congratulations and compliments for it. Samuli is not a native German speaker, and the translation was hardly up to the quality of the original, but this bothered nobody. There were in fact no German speakers among those who complimented S. for his poem being translated. Nobody asked us if and how the translation might reach a German audience (it probably did not). The less internationally connected writers are, the more translation is primarily a marker of status for them and only secondarily, if at all, a way to reach global audiences.

Language is a more complex issue. In poetry, a well-established division runs between Classical and Egyptian Arabic - each of which has specific connotations and symbolic status: colloquial is associated with accessible, down-to-earth, humorous writing, while Classical Arabic is linked with more highbrow or conservative uses. Owing to the declining quality of public education (and the dominance of English in upper-class private education), younger writers often barely master Classical Arabic grammar, and we often encountered works of prose that 
fluctuate between colloquial and classical registers not as a conscious aesthetic strategy, but simply because the author lacked proficiency in Classical Arabic. While Classical Arabic enjoys high symbolic status as the language of national and religious traditions, it is not a marker of high social status in Egypt, where the global-local distinction is a cornerstone of class. English comes with higher social prestige, and in some intellectual and artistic scenes in Alexandria it is preferred as the language of intellectual conversation - to the disgust of those who have not mastered it. Some aspiring writers who socialise in the international educational sector also write in English (which along with French has some tradition in Egyptian literatures of the twentieth century, see e.g. Ghaly 1964), and yet Arabic clearly dominates at literary events and publishing: we have met many accomplished and internationally connected writers whose English is moderate at best. Translation into Arabic flourishes since the early 2000's, and is a major source of international connections in literary movements, although many readers complain about the poor quality of many translations.

Despite its relatively provincial nature when assessed against its large size as a city of over 5 million inhabitants (CAPMAS 2017), Alexandria has a lively landscape of reading, writing, and debate. The focus of our fieldwork has been on a range of literary scenes and spaces that owing to their lack of commercial opportunities largely stand on the elitist side of the first of the three formative tensions described by Pepe (2019b). This does not mean that the writers we met were elite, or even that their works were generally highbrow (many are strongly influenced by commercial literature), but they generally share a highbrow aspiration to write literature that is distinctive in one way or another. They differ greatly, however, with regard to the second and third tensions described by Pepe: moralism versus licence, and societal commitment versus aesthetic exploration.

These tensions were clearly linked with infrastructures and social circles during our fieldwork. In the following, we explore those linkages at four sites we regularly attended, and which are each linked with specific circles and a specific milieu.

\section{The Writers' Union}

Our most long-standing fieldwork site (from 2012 to 2019) was the Writers' Union, officially called The General Syndicate of the Writers' Union of Egypt, Alexandria Branch. This is a national institution, and as the name indicates, it is a selfadministered syndicate that represents writers' professional interests. National and branch boards of the Union are elected by members in biannual elections. 
To become a member, one must present at least two published books. Members pay a fee and are entitled to some modest services. The Writers' Union was once a dominant institution, but has gradually lost some of its importance as younger writers are less likely to join and attend its meetings.

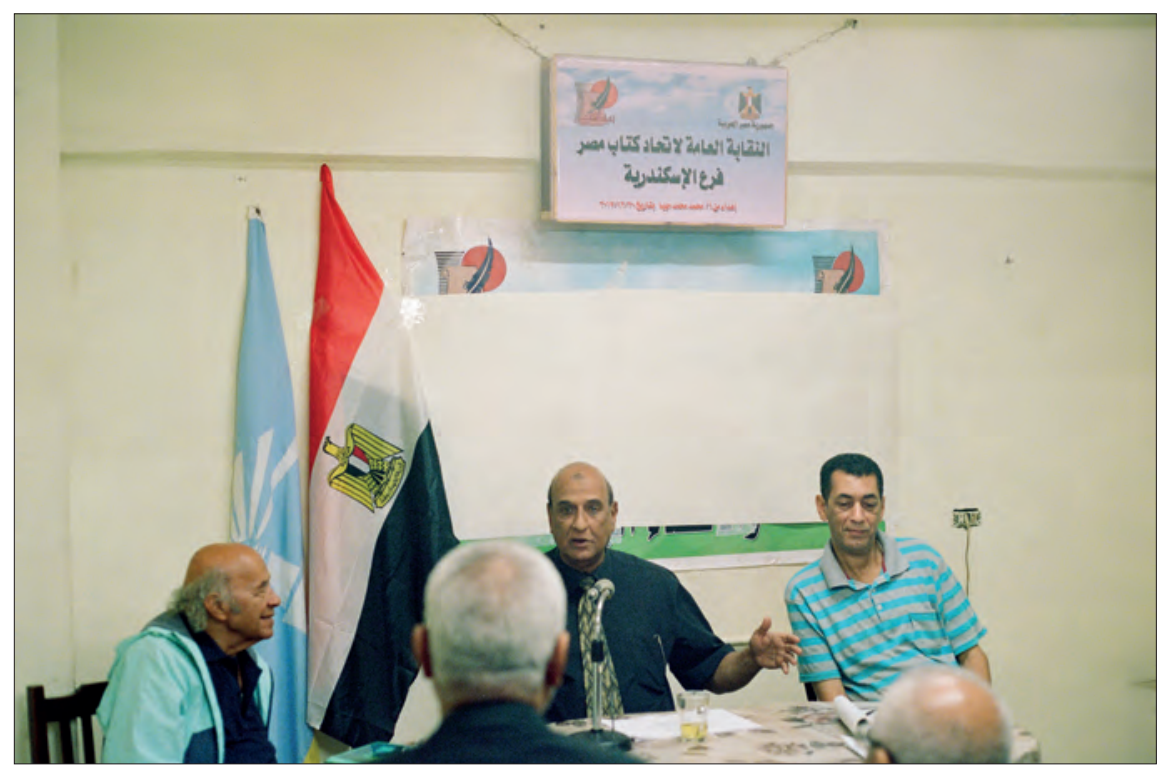

Image 2: A symposium at the Writers' Union, November 2019.

The Alexandria Branch of the Union occupies a ground-floor apartment in Miami, a neighbourhood in the East of the City, the most populous part of Alexandria. The Writers' Union is part of a wider scene of public-sector institutions and social circles associated with them. Often those who frequent the Union are also active in literary events at public-sector cultural centres run by the Ministry of Culture, and a similar spectrum of literary currents and participants can be found at both. During our fieldwork, there were at least three main currents present at meetings of the Writers' Union.

The first current consists mainly of poets born in the 1960s and 1970s who represent an avant-garde wing in the Union. Two among them introduced us to the Union in the first place: Kamal Ali Mahdy and Ashraf Dossouki Ali, whom Mukhtar has known for a long time, and whom Samuli met through our meetings with Kamal's circle in a café in the nearby neighbourhood of Abu Kharouf (featured in Chapters 1 and 4). They both write modernist poetry in Classical Arabic, sympathise with literary innovation and exploration, and also feel at home in the public-sector spaces of the Writers' Union and cultural centres. They stand 
in a tradition of the Writers' Union as a space where literary avant-gardes could struggle for power in the literary establishment - a tradition that is becoming weaker, however, as fewer young writers with such ambitions want to join the Union.

The second current consists of a variety of authors who stand in a more conservative tradition of twentieth-century modernism, ${ }^{7}$ highlighting the idea of literary commitment that is able to guide society, and a moralistic vision that links literary imagination with a conservative understanding of $a d a b$ as the cultivation and teaching of fine manners. Their works of prose are often based on straightforward narration, and their poetry tends towards either classical double verse or its colloquial counterpart zagal. Among the representatives of this current we encountered was the novelist B.S., originally from Palestine and living in Alexandria for decades. At a symposium dedicated to her work in 2015, she rejected experimentation and innovation in literature (attacking surrealism in particular), identified with an Arabic and anti-Western literary and political nationalism, and insisted on morally and politically committed literature that would only use polite and decent language. At the same time, she took pride in her knowledge of Russian and French classics, and took for granted modernist narrative genres such as the novel, which a hundred years earlier had been new innovations of partially foreign import. Not all writers in this conservative current are as straightforward in their rejection of experimentation, however. Others are engaged in explorations within the guiding limits of moral and committed literature, with an example being Gamal Kashhat (who appears in Chapter 5), who has experimented with speculative fiction and reflected on how science fiction could be put to work to find solutions to climate change.

A third current consists of new writers, most of them at retirement age. The retirement age in Egypt is low (sixty in most sectors, and early retirement is easily available in the public sector. Some men and women in their fifties and sixties who are financially secure can stop working, and when they find themselves with free time they are able to pursue literary interests. While younger new writers we met typically sought other sites of activity and rarely ventured to the Writers' Union, older writers were numerous at the weekly symposium. Their writings were often highly autobiographical, and the conflicts they addressed often

7 We speak of modernism in the sense of a cultural and political movement that links forwardlooking independent arts with a top-down nationalist struggle for progress and development, an appropriation of Western cultural production and standards, and a search for national, religious, or other forms of authenticity. See Armbrust (1996); Jacquemond (2008). 
related to family life, professional experience, and social engagement (see also Šabasevičiūtè 2019a).

A primary accomplishment of the Writers' Union is its ability to host a plurality of literary tastes and stances, and also degrees of experience and skill. This is further complicated by political differences between regime supporters (including former communists who became regime supporters in 2013 because El-Sisi and the military represented for them a nationalist and secular hope for rescue from Islamism) on the one hand, and regime critics (many of whom entertain various degrees of Islamist sympathies) on the other. A key task of the moderator of a symposium at the Writers' Union is to systematically downplay and evade these and other differences that could easily destroy a meeting. What keeps the Union together therefore appears to be neither aesthetics nor politics, but rather a generationally specific commitment to public-sector institutions and, for most but not all participants, a commitment to a tradition of twentieth-century modernism in which an elitist idea of the author is combined with a pedagogical and engaged view of literature.

\section{Mukhtabar al-Sardiyat}

Established in 2002, the Bibliotheca Alexandrina is the leading cultural flagship in the city. It hosts a large and varied cultural programme, from small workshops and symposiums to large concerts and readings by popular performers, as well as large conferences and an annual book fair. The Library, as it is usually referred to, stands directly under the authority of the President of the Republic and is the main beneficiary of international cultural and scientific funding in Alexandria. It is also a major employer in the cultural sector.

The Library hosts a number of autonomous cultural initiatives, among them two important literary circles: the Itlala literary group and Mukhtabar al-Sardiyat (the Narratives Laboratory). Mukhtar conducted fieldwork at al-Sardiyat from 2015 to 2017, occasionally accompanied by Samuli who returned there to attend a handful of events in 2019. Having had its first meeting on 29 December 2009, al-Sardiyat is one of the more long-lasting literary initiatives in Alexandria, and is closely connected with its founder Mounir Oteiba, who programmes and moderates all the events.

Al-Sardiyat is a debating club that meets weekly at the Alexandria Library, each time presenting and discussing a literary work by an invited author. The works presented vary greatly, ranging from traditional modernist narratives to more exploratory or experimental approaches. The group has featured well- 
known authors enjoying national recognition (and occasionally Arab writers from outside Egypt) as well as young local writers presenting their first book. The format is always the same: an author reads passages from his or her work, two discussants give a critical reading of the text, to which the author is invited to respond, and the audience adds interpretations and comments. Mounir Oteiba moderates the discussion and adds his comments when he deems this necessary. The format of a critical debate (munaqasha) is well established in Egypt, and can be found in many settings, but unlike most places, which feature a variety of formats, al-Sardiyat is exclusively dedicated to this one, giving it a formal consistency that few other literary spaces possess.

The regular crowd at al-Sardiyat includes middle-aged and older people whose tastes and styles of critique and debate come close to those in the Writers' Union, as well as younger participants who had their first experiences of literary sociality in writing workshops held in independent spaces. Al-Sardiyat has also been able to attract many women writers of all ages, and Mounir Oteiba actively encourages their participation as authors and discussants. Al-Sardiyat is located in a recognised state institution and is embedded in a more formal, thus also more morally respectable, form of mixed-gender socialising than many independent spaces. Thus, it allows women writers to balance conservative social mores and the development of a public literary voice.

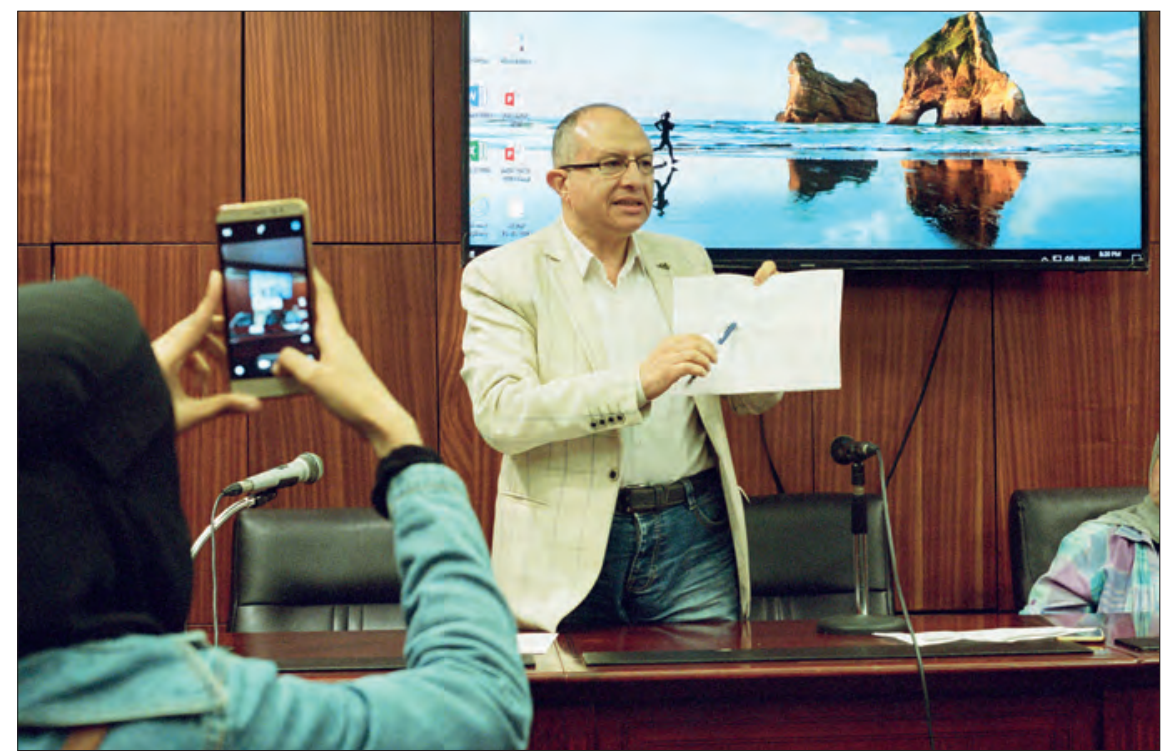

Image 3: Mounir Oteiba discusses narrative technique at Mukhtabar al-Sardiyat, November 2019. 
Al-Sardiyat has been designed by Mounir Oteiba as a space that brings together different literary groups and tastes, and it is remarkably successful in that regard. It is the only literary gathering we attended that has regular crossovers in terms of participants and visitors with all the others we know. The organiser's motivation, to bring together and unite, is evident in the variety of authors and works discussed, and also in the style of debate, which carefully bridges the two contrary dimensions of literary critique: questioning and exploration, and a performance of recognition and status affirmation for authors.

The focus on critique gives al-Sardiyat a pedagogical aspect that is explicitly appreciated by some participants we spoke with. It is designed as a learning space where participants are encouraged to think about the why and how of literary themes and techniques, with the explicit aim to 'say something that has not already been said', in the words of Mounir at one of the meetings in November 2019.

This is the main difference between al-Sardiyat and events we attended at the Writers' Union and public-sector cultural centres. The latter focus more on recital and recognition, and pay less attention to innovation and the development of skill. The idea of writing as a trained skill that allows an author to say something new is aligned with a shifting ideal of authorship that has been promoted by literary avant-gardes since the 1990s. In Mounir's words (at a discussion in a café after a meeting in September 2019), there has been a historical shift from the writer 'as a sort of prophet with a mission and with supreme inspiration (ilham), to the writer as one among others who is observing, working, and asking'. The consequence, he argued, is that writers are better advised to forget inspiration, and instead recognise that talent needs to be developed and trained.

Mounir's ideas about writing and authorship stand in a productive tension with the explicit inclusivity and pluralism of al-Sardiyat. Such a combination is not easy to maintain. In other circles we know, inclusivity tends to go hand in hand with more conservative aesthetics, and avant-garde explorations need a degree of closure to thrive. Mounir Oteiba's presence is instrumental in creating a balance. By having the last word as the programmer and moderator of al-Sardiyat, he can run an inclusive programme to his own taste that otherwise might fall apart owing to aesthetic differences and power struggles.

\section{El Cabina}

El Cabina was a cultural space active from 2010 until August 2016, located in a technical building ('cabin', hence the name) at the back of the abandoned, and later demolished, Cinema Rialto in the downtown district of Raml Station. El 
Cabina was run by the Gudran Association, an internationally funded cultural NGO that was established in 2003 and closed in 2018. It featured a library and a music studio, and a varied cultural programme of concerts, movies, exhibitions, intellectual and literary readings, and debates. Its period of activity coincides with the vibrancy of cultural life in the wake of the 25 January revolution, and its end corresponds with the gradual tightening of the grip over independent cultural institutions in the aftermath of the counter-revolution of 2013. We frequented events at El Cabina throughout its period of activity (some events we attended are featured in more detail in Chapter 5).

The audience that gathered at El Cabina's literary and intellectual events was varied in terms of age. There were usually many female participants, and many among the audience sported a bohemian or alternative habitus of the kind that was becoming increasingly popular, especially among young urban supporters of the so-called revolutionary current that emerged in 2011. Regular participants hailed from urban families but not just from the bourgeoisie; many of those active in running the events were in their thirties or forties, and originally came from the old popular (sha'bi) quarters of Alexandria.

The poet Abdelrehim Youssef told Samuli in 2019 that when he and other members of Gudran designed the literary programme of El Cabina, they decided not to reproduce the format of an open weekly symposium (such as the one held at the Writers' Union) that by its nature is inclusive and thus of mixed quality. Instead, they chose dedicated meetings with selected authors of 'serious literature' (adab gadd), which in practice meant writers who were part of the internationally connected cosmopolitan avant-garde, including some newly emerging genres such as the graphic novel.

Events were focused on debate and critique. The mood and tone of address was much less formal than in most other spaces we attended. Instead of reading out a written study, discussants made improvised comments and asked the authors unscripted questions, engaging them in an open-ended conversation. There was thus an explicit and also embodied preference for the exploratory and questioning dimension of critique, and an aversion towards laudatory performances of critique as recognition. In terms of the second productive tension in Egyptian literature that Pepe (2019b) describes, the literary programme at El Cabina stood in between the ideals of autonomous text on the one hand, and the idea of writing as a critical, potentially committed practice on the other. In regard to the third tension, it certainly preferred licence to moralism. In terms of the first tension, elitism versus popular taste, it leaned towards highbrow aesthetics combined with an openness for some popular cultural styles that were part of the emerging alternative or 'independent' aesthetic. This latter element was especially pronounced in the venue's music programme. 
Some people active in other literary scenes criticised El Cabina for reproducing and promoting the taste and works of a shilla and by so doing excluding outsiders. However, the reliance on shilla networks is a feature of all cultural circles in the city. It makes shared work possible, but it also generates limits to aesthetics and collaborations that are difficult to cross. What is an aesthetically ambitious selection of good literature for some, for others may appear as favouring the taste of one shilla over others. Abdelrehim acknowledged in hindsight that the literary programme's cutting-edge ambition occasionally functioned at the expense of outreach. However, readings of well-known authors such as Sonalla Ibrahim in 2011 attracted very large audiences; while the Nuqaddim lakum (We introduce to you) series on social theory was extremely popular despite its demanding content: it met with a demand from a sufficiently large sector of people for interpretations in theoretical terms of what was going on in their society.

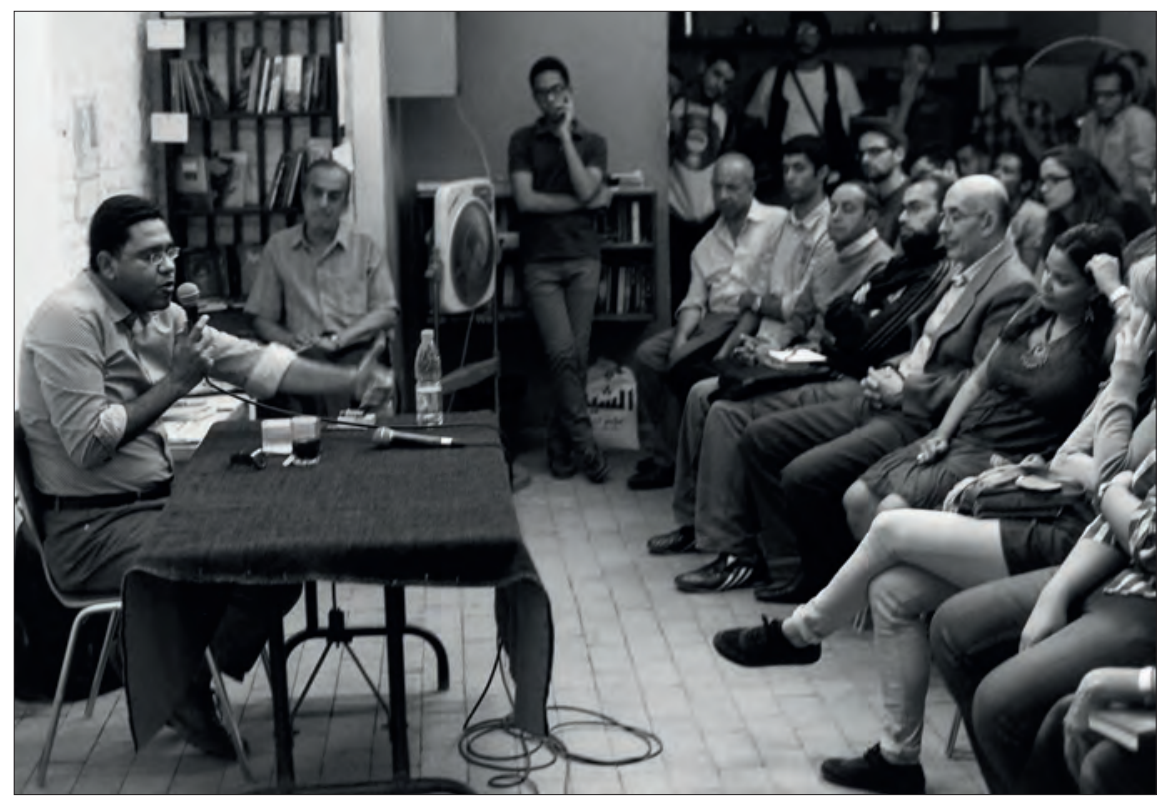

Image 4: Amr Abdelrahman presents the work of Karl Marx at the Nuqaddim lakum (We introduce to you) series on social theory at El Cabina, October 2014.

El Cabina was a successful space, and yet its success was largely limited to a milieu for whose tastes and interests it catered. However, such a limited reach is a feature of almost all cultural sites in Alexandria, with the exception of the Alexandria Library. A degree of limitation makes a space attractive because it provides participants with a sense of comfort and ease, and programming they will appreciate. This made El Cabina an informal meeting point for a circle of writers 
who had known each other for a long time, as well as musicians and other cultural practitioners who gathered there (Asfour 2020). Their network preceded El Cabina, and has remained active since its closure.

The literary and intellectual programmes at El Cabina were just one among the many projects undertaken by a circle of writers and other artists who have a taste for debate and experimentation, often combine literary with intellectual engagements, have participated in various shared projects, are often linked with the internationally funded independent cultural scene, and prefer to gather at al-Bawwabin, a small street café in downtown Alexandria that is known as a meeting place for writers and performing artists in the city (Youssef 2015). The oldest members of the circle were born in the 1960s and 1970s and were involved in the 1990s literary avant-garde, but it has continuously recruited younger members.

The first public manifestation of this circle was the literary group Al-Kull (Everyone), which gained some prominence in the 2000s. According to Abdelrehim Youssef, who entered the literary scene by this route in the early 2000s, al-Kull was originally the title of a book series edited and designed by the short story writer, literary critic, illustrator, and graphic designer Maher Sherif. Rather than being a coherent literary group, al-Kull was something like a trademark that was generated by Maher, who appreciates debate and difference and is known as an uncompromising literary critic. Consistent with his taste, al-Kull had no distinctive aesthetics other than its propensity for plurality and questioning.

Al-Kull ceased to exist as a literary identity in around 2010 without ever being properly dissolved. According to Abdelrehim, the most important aspect of the group was its members' collaborations, such as the journal al-Mina (The Harbour) of which a handful of issues were published in the mid-2000s. Another journal project, largely produced by the same circle, Tara al-Bahr (Sea View), was published in 2016-2017 and is featured in Chapter 5. By the late 2000s, some members of the circle joined the Gudran Association, which in a few years grew from a community project for a traditional fishermen's settlement into a key actor among independent cultural institutions which proliferated in the 2000s thanks to an influx of international funding. In 2008, Gudran opened an art space called El Dokan in a shop in the downtown district of El-Manshiya, followed in 20102011 by El Cabina at Raml Station, and in 2014 by Wekalet Behna, in an old office building in El-Manshiya, which was dedicated to visual arts and film. Gudran became an important employer in the cultural sector, employing at its peak as many as twenty-four people in different projects and spaces, mostly on part-time contracts. Abdelrehim Youssef and Omayma Abdel Shafy, who had published in the al-Kull series, became employees of the association, with the former working as a teacher and translator at the same time to make ends meet. 
El Cabina closed in August 2016 when the lease for the space could not be extended. By this time, Gudran was running out of money, and it gradually stopped paying salaries. Funding had been approved by the Ford Foundation, but Egyptian authorities refused to release the funds. Gudran was finally dissolved by court order in May 2018: an administrative error connected with the receipt of funds provided an opportunity for measures to be taken against the association. This coincided with a restrictive new NGO law and similar measures against other NGOs in Egypt. Gudran's employees dispersed, some returning to their former commercial careers, others seeking freelance work in translation or cultural projects abroad. In September 2019, the court order was overruled on appeal, but Gudran's end was irreversible. Previous employee Omayma Abdel Shafy together with Basil Behna established Wekalet Behna as a private company, which focuses on hosting visual arts, archival research and alternative education (notably the Alexandria branch of the Cairo School of Liberal Arts and Sciences) within its premises at a time when outreach to the street is not feasible.

\section{Fabrica}

The independent cultural scene that flourished from the early 2000s until around 2015 was properly speaking only independent from the Ministry of Culture. Cultural production is always dependent, be it on private or public funders, or on markets in the case of commercial productions. When Samuli returned to Alexandria in autumn 2019, he found that numerous private cultural initiatives remained active or had been recently established in spite of the difficult circumstances. But their scope was more modest, their budgets were smaller, and their sources of revenue more heterogeneous (such as renting out spaces, running a café, and organising workshops, and often with organisers investing their own money from freelance income) than was the case at the beginning of the decade. Paradoxically, the independent institutions were now more independent because they were less bound by funder bias - but in turn they were much weaker.

Such private initiatives have a long history in Alexandria, but most of them have only lasted a short time. One of them, Fabrica, was a regular site for our fieldwork in 2014 and 2015. It was established in 2013 in the old bourgeois/ middle-income district of Sporting, south of downtown Alexandria, as the private enterprise of its founders, the writer Alshimaa Hamed and the graphic designer Ahmed Salem. Unique in being a dedicated literary establishment, it featured a cultural space that simultaneously served as café and bookshop, while it also 
operated as a publishing house with a focus on comics and offered a programme of writing workshops.

During our fieldwork in Fabrica in 2014 and 2015, Alshimaa Hamed (who told us about her early literary career in Chapter 1) ran a successful programme of literary events and writing workshops in the space, and turned it into the meeting place of a small circle of people with similar interests and attitudes (more about the workshop and some of its participants in Chapter 3). The crowd at Fabrica was younger than in any of the other places we frequented. Women were in the majority. With few exceptions, the participants came from the bourgeois classes of the city. Many of them had spent their childhood in the Arab Gulf states where their parents lived, and returned to Egypt to study.

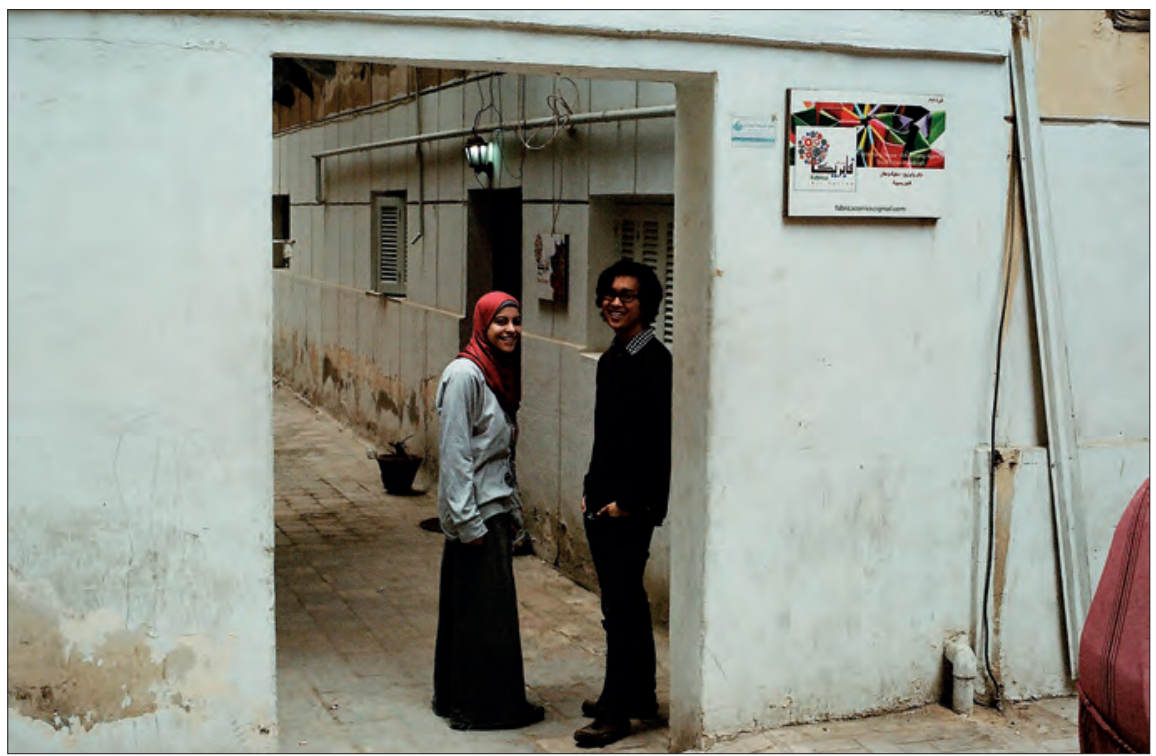

Image 5: The entrance of Fabrica, March 2015.

The literary aesthetics of Fabrica were balanced between highbrow literary ambitions and what in Egypt is called underground (as an English loan word) or independent (mustaqill). The latter term has been used to describe cultural NGOs and self-organised theatre companies alike, but it also describes a genre of music from the 2000s to 2010s that combined Western rock and pop tunes with Arabic ones (Anonymous 2020; Asfour 2020; Sprengel 2020d), as well as other genres of global circulation that are mainly accessible to young people with cosmopolitan capital (through education at international schools or diasporic lives), such as 
graphic novels and comics. The latter were at the heart of Fabrica's publishing activities thanks to Ahmed Salem's love for the genre.

Like many others of its kind, Fabrica was short lived as a cultural space. This was mainly owing to a lack of revenue. Alshimaa Hamed left Fabrica in summer 2015. The space remained active, but Ahmed Salem was compelled to close it later the same year, when he moved to Cairo to run Fabrica as a publishing house dedicated to comics. At the time of writing (2020), Fabrica still exists as a company, but Ahmed Salem has largely given up the publishing business, having returned to Alexandria and his original trade of graphic design.

While Fabrica did not last long, Alshimaa's literary circle had more staying power. Her original literary socialisation took place at the Writers' Union and in various other cultural centres, but after the publication of her first book, she became active in the emerging scene of independent institutions. Through writing workshops (the first of which was hosted by El Cabina) that started running in 2011, she formed a circle of her own, consisting mostly of young and female aspiring authors (about whom more in Chapter 3). After Alshimaa moved to Cairo, the circle she established remained as a network of friends, but appears no longer to be a primary site of active literary production and circulation.

In 2019, private cultural projects in the city were taking a more commercial and aesthetically inclusive approach. Some such as Tarh al-Bahr (established in 2015) have been able to remain active for several years thanks to commercial revenue. Some others have made use of spaces provided by the gentrification project of a real estate consortium at Fouad Street in the old up-market neighbourhood of Azarita. When Samuli met Ahmed Salem (who had returned from Cairo a couple of years earlier), the latter mentioned favourably Beram w Sayed, ${ }^{8}$ a privately funded cultural space and café that was established at a prominent location in Raml Station in 2017. It and its like, Ahmed argued, were a new and successful version of what he and Alshimaa had tried with Fabrica. All these places appeal to a mixture of bourgeois and alternative-bohemian tastes, but they tend to be more inclusive than their predecessors in terms of their aesthetics and programming. Privately run places, it seems, have to be distinctive enough to attract an audience, but they cannot afford to be too demanding (Elnozahy 2020).

8 Named after the colloquial poet Bayram al-Tunsi and singer Sayyid Darwish, two of the most prominent cultural icons of early twentieth-century Alexandria. 


\section{Lines of division}

In a working paper written and published during our fieldwork (Schielke and Shehata 2016), we described the social lives and divisions that structure literary life in Alexandria through a binary model of conservative versus avant-garde milieus, the first marked by public-sector institutions, and moralist and committed aesthetics, and the second by so-called independent institutions, with exploratory and experimental aesthetics. Some Alexandrian writers who read our paper (notably Mounir Oteiba and Ahmed Abdel Gabbar) criticised it for reducing the plurality of the city's literatures to just two scenes. Indeed, far from being divided into two separate camps, the literary landscape of Alexandria consists of a large number of literary circles or 'pockets' (Shehata 2020). Each of these produces and circulates its own aesthetic and social standards for good literature; at the same time, these numerous circles are grounded in a smaller number of milieus, which all share in a wider field of cultural production. Rather than being closed entities, these milieus can be best understood as intersections of lines of division, which we explore in more detail in this section.

Vast common ground extends across literary divides, making literature recognisable as a social institution despite its many internal divisions. Key genres such as classical and modernist poetry, the novel, and the short story are established or at least acknowledged in practically all literary scenes. While poetics is a more contested issue (see Chapters 7 and 8), the basic literary conventions of the novel and the short story remain largely consensual, and lines of division within prose genres are marked by other issues: the preference for established forms or experimentation, the idea of authorship involving moral authority or not, and the use or avoidance of explicit sexual language or themes. Performative formats such as the symposium (nadwa, see Chapter 3) are cultivated in similar shapes across the spectrum, and major events such as book fairs bring together authors and readers of all tastes. Mediums of recognition such as prominent publishers, critical essays, and literary prizes are sought in almost all circles, even while people in different circles have distinct ideas about which publishers are good, what critique should be about, and which prizes matter. There is also a widely shared national canon of major twentieth-century writers and the larger Arabic canon of moderns and classics. Alexandrian novelists who have gained national and international recognition - such as Edward Kharrat (1926-2015), Ibrahim Abdel Meguid (1946-), and Haggag Adoul (1944-) - are generally recognised and respected across the literary spectrum, even while their politics and aesthetics may be contested.

The most notable aesthetic line of division we encountered runs between experimental, globally connected styles and socially controversial themes on 
the one hand, and the commitment to a conservative selection of the twentiethcentury canon of national and world literature and a morally constructive ideal of literature's social role on the other. ${ }^{9}$ This line of division largely - but not fully aligns with two of the productive tensions outlined by Pepe (2019b): writers with a more conservative commitment to literary forms that were established in the twentieth century were also more likely to consider literature as a moral mission (the second tension according to Pepe), and to think of writers as organic intellectuals who could and should speak to the masses (the third tension according to Pepe). In contrast, globally connected writers with avant-garde ambitions in the early twenty-first century have tended to consider literature and literary pursuits as autonomous, thus searching to explore rather than to moralise and to guide. ${ }^{10}$

However, the categories 'conservative' and 'avant-garde' are unstable because they are subject to a constant generational transformation. Genres and aesthetics that are conventional today were once controversial and new - such as the free-verse poetics of tafila (for more on poetics, see Chapters 7 and 8). Claiming to represent the new against the old is an established and often tactical gesture in struggles for literary recognition and power (Šabasevičiūtè 2021). The careers of successful senior authors are often marked by a move towards the centre of institutional power with growing age and influence. State-affiliated cultural institutions have a long history of co-opting the critical and creative energy of the avant-garde. The Alexandria Library is quite successful in this regard. Last but not least, the competing aesthetic positionalities articulated along this line of division - or, to be precise, the specific aesthetics and people that occupied those

\footnotetext{
9 Twentieth-century Egyptian literature included some very experimental and controversial works, and much of it was closely linked with international literary currents. And yet the way in which the heritage of the twentieth century is reproduced and recognised in places such as the Writers' Union tends to highlight uncontroversial writing and nationalist commitment. Experiments are recognised once they have become established as part of the mainstream - as happened with the novel in the early twentieth century and free-verse poetry in the second half of the twentieth century.

10 This does not mean that political or social commitment would be alien to them. On the contrary, our period of research witnessed a dramatic intensification of politically engaged writing in the wake of the 25 January revolution, and even people who showed little political engagement before and after the revolutionary period were politicised. But the avant-garde ideal popular among their generation depicted the author as one among many, speaking from within the revolutionary crowd rather than preaching to the masses from above. It also promoted the ideal of autonomous text or 'pure literature', in the words of the internationally successful novelist of Alexandrian origin Nael Eltoukhy (2019), which would engage with issues of contention but not act as a mouthpiece for the author's stance.
} 
positionalities in the historical moment of the 2010s - often shared a highbrow ambition to produce 'serious literature'.

A divide between highbrow and popular aesthetics and audiences was therefore very pronounced in our fieldwork, even if it was often unclear what fell into which category. While commercial literature ignored by highbrow literary critique has a long history in Egypt (Bawardi and Faranesh 2018; Selim 2019), the 2000s witnessed the emergence of bestseller novelists, including Ahmed Mourad (Jacquemond 2020), Ahmed Khaled Towfik, Nabil Farouk (Bawardi and Faranesh 2018), Alaa El Aswany, and Youssef Ziedan (currently the only bestseller author from Alexandria). The careers of Towfik and Farouk exemplify a shift in recognition: they started their careers as exceedingly prolific writers of quick and cheap pocketbook fiction, then gradually moved 'from the margins of literature to its center' (Bawardi and Faranesh 2018: 34). The career of Ahmed Mourad reveals the importance of active use of online media along with a close alliance with cinema and television production (Jacquemond 2020). The latter has been an established feature of Egyptian literature ever since the Egyptian movie industry began, with film and telenovela (musalsal) adaptations being the most important path through which works of literature can become known to a wider non-reading audience, and bring substantial financial profit for their authors (Jacquemond 2008).

Many writers we met looked down upon commercial literature. Cairo-based bestseller novelists such as Ahmed Mourad or Alaa El Aswany or popular colloquial poets such as Hisham El Gakh were often discussed with ridicule, in some cases with disgust - even by authors whose own writing was no more complex or demanding than that of the stars they deprecated. On occasion, people who had little chance of ever making money from writing proudly insisted that writing for money could not be real literature. Others were less adversarial, considering commercial literature to be something worth recognising for its own sake, and perhaps also helpful in encouraging young people to read, but nevertheless they clearly considered their own work and works of others they liked to be of a different category, that of 'serious literature'.

However, people who share highbrow ambitions might also consider each others' work cheap and popular rubbish, poor writing by beginners, or improper vulgarity. Only a fraction of all those who claim to belong to a literary elite are actually recognised in literary centres of power - by being published by a major publishing house catering to the cosmopolitan avant-garde, by being favourably reviewed and read by significant others, by being granted one of the many prizes funded by the Egyptian state or private sponsors in Egypt or the Gulf (each of which promotes different literary tastes), or by being invited to international 
events, such as festivals in Europe for the cosmopolitan avant-garde or competitions and recitals in the Gulf for classical and popular colloquial poets.

In his work on the literary field, Pierre Bourdieu (1998) argues that the symbolic capital of the avant-garde and the economic capital of commercial literature stand in inverse relation to each other. The ability to dispense with economic profit is a requirement for recognition in what Bourdieu calls the 'legitimate field' of literary production, which draws its power and prestige from critical recognition rather than sales. But unlike in France (Sapiro and Rabot 2016), extremely few writers in Egypt are able to gain substantial financial profit from literature, and those few who do almost invariably live and work either in Cairo or abroad. In Alexandria, even writers who consciously employ an accessible, popular style usually only reach limited audiences, and most writers have a very small readership. ${ }^{11}$ The main line of competition among the literati in Alexandria is not drawn between a 'legitimate field' of autonomous literary production for a restricted audience on the one hand and a wider field of mass production on the other; rather, it is mainly between people who write for different small circles, and who claim that they, rather than any others, are the 'legitimate field' of 'autonomous literature' (to use Bourdieu's terms).

The distinction between popular and highbrow is further complicated by the emergence of what may be called an independent or alternative aesthetic. A socially recognisable alternative habitus emerged in Egypt on a wider scale after 2011, associated with sympathy for the so-called revolutionary current, a class positionality on the bohemian fringes of the bourgeoisie, and a cosmopolitan competence in cultural styles and productions of global currency. In our fieldwork sites, avant-garde and alternative aesthetic stances often went hand in hand. However, because its distinction is based on cosmopolitan capital, alternative aesthetics is not posited in opposition to popular literature in the way of highbrow stances. The popularity of the bestseller science fiction and horror author Ahmed Khaled Towfik among some of our interlocutors who leaned towards an alternative aesthetic is a case in point. This independent or alternative taste has welcomed commercial venues and popular-class (shaabi) aesthetics alike (Sprengel 2020d), while its distinctiveness lies in the exploration of specific styles, genres, and lifestyles that are posited as explicitly different from a mainstream, whether this be defined in terms of aesthetics, politics, or class (Lagrange 2020: 19).

11 Typical print runs for works of literature run between 500 and 1,000 copies, and for most works (with the exception of prominent authors), the main channel of distribution remains authors themselves, who receive or buy copies from the publisher and give them to friends and peers free of charge. 
While our fieldwork was taking place, these aesthetic divides were to an important degree linked with an institutional divide between public-sector, independent, and commercial institutions, which emerged in the wake of the professionalisation of private publishers and the onset of the NGO-isation of the cultural sector at the turn of the millennium. ${ }^{12}$ In Alexandria, this development involved the migration of some writers into new scenes and spaces that were established in the mid-1990s and 2000s, along with new journals such as Khamasin and al-Mina. By 2020, parts of this divide have been crossed with the increasing pressure on independent institutions and a renewed vibrancy of some public-sector institutions. And even at its height, this divide was never complete. Well-funded cultural flagships such as the Hurriya Centre for Creative Expression (Markaz al-Hurriya li-l-Ibda') and the Alexandria Library draw audiences from across the cultural spectrum. They are also important providers of jobs for people who are otherwise active in independent spaces. All major book fairs are state sponsored. Major public-sector publishers such as the General Egyptian Book Organisation and the Organisation of Cultural Palaces remain points of first contact for writers connected with public-sector cultural institutions - and also for writers who lack the funds to pay for a private publisher. They also maintain a leading role in translated literature.

The third pole of the institutional divide - commercial institutions - is mainly located in Cairo. There, profit-based enterprises are at the heart of literary life, with a handful of high-end private publishers largely defining the scope of the internationally connected avant-garde in literature, another handful of professionalised commercial publishers manufacturing bestsellers, and many writers making their living as editors, proofreaders, or translators in those publishing houses. In Alexandria, a handful of bookshops and profit-based cultural spaces have been able to stay in business, but almost all literary publishers that were still active there in the early 2010s have gone out of business since then.

The tensions that mark the literary landscape in Alexandria bear striking similarities with those among Afghan poets in Mashhad, Iran, studied by Zuzanna Olszewska (2015). The poets in Mashhad were embedded in a productive tension of different forms of class, power, and symbolic capital, but were seldom polarised along the opposites of literary autonomy and commercial production. Rather, there was a generational shift from politically committed poetry of firstgeneration refugees to a plurality of styles in a continuum from committed to post-

12 This process has been best studied in terms of the art scene (e.g. Winegar 2006: 275-314; Elnozahy 2020). 
modern writing among Afghans born and raised in Iran. The societal and political situation is in many ways different in Alexandria. Most Alexandrian writers in the early 2010s had not experienced exile, although things have shifted since then, and Nubians, Syrians, and Libyans living and writing in Alexandria today do have a shared experience of exile or diasporic conditions (see, e.g., Al-Ahmad 2014). And yet Olszewska's work draws attention to the ways in which politics (something that does not fit well into Bourdieu's model), relations with the state, gender, and generation interact with class relations and symbolic capital.

Similar attention is needed if we are to understand the structuring divisions of the literary field in Alexandria, for which the aesthetic and institutional lines of division sketched out here do not alone provide a sufficient account. The public sector is vast and encompassing. It offers a venue for a variety of literary productions, from older generations of avant-garde writers to classical and popular poetry, while at the same time promoting cultural policies of the state aimed at educating the public. Commercial private publishers have their highbrow and commercial niches, and are partly subsidised by translation funds from abroad. Political allegiances and enmities cross over aesthetic divisions, or can be downplayed to keep a milieu intact. Many aesthetic currents and institutional locations are associated with a specific generation and social class. To understand these specific locations, we need to consider a series of less clearly defined multipolar divides that also shape literary milieus.

Politics and religiosities mark the most outstanding multipolar divide in the literary landscape, involving different positionings towards revolutionary politics in 2011-2013, Islamist and secular ideologies, different views of the political regimes before and after the revolution, and various commitments to nationalism.

If, in around 2011, literature initially appeared to be a natural ally of rebellion (Schanda 2013), political divisions within the literary field became more evident after 2013, when prominent authors previously known for their oppositional stances rallied support for the new regime and the military leadership (Lindsey 2013; Azimi 2014). This move can partly be attributed to the long-standing antagonism between secular-minded literary intelligentsia and Islamist movements. But rather than uniting a secular literary field, it divided it further: between an often older guard of leftist nationalists committed to a Fanonian binary struggle for national liberation in which there can be no neutral position, versus often younger authors and activists who sought to articulate a third position against both the regime as well as Islamists. ${ }^{13}$

13 Frantz Fanon (2004) famously argued than in the struggle for national liberation there could be no third neutral stance. Egyptian leftists lending their support for Sisi's military regime have 
Political and religious stances have the power to bring together a literary circle, but they can also contribute to its breakup. This is what happened to Hala ('condition' or 'case'), ${ }^{14}$ a literary group that was initiated in 2009 by a group of poets from eastern districts of Alexandria and held its meetings mostly in cafés in those neighbourhoods. The group initially cooperated with the weekly literary symposium held at the social club al-Nadi al-Masri (more in Chapter 3). The two groups shared a similar conservative modernist aesthetic and a liking for colloquial poetry, but their cooperation ended largely for political reasons. Al-Nadi al-Masri was a politically loyalist space, while Hala was frequented by poets who were critical of the regime and sympathetic towards Islamist movements. In 2012, Hala fell apart owing to political differences that turned personal, but it continued as an informal gathering of some of its initiators, including the poet Hamdi Mousa (featured in Chapters 1 and 4). One of the group's former members ran a literary programme at the office of the Freedom and Justice Party (the political arm of the Muslim Brotherhood from 2011 to 2013). The programme was disbanded along with the party after the counter-revolution in 2013, and the people active in it dispersed.

Some other circles have been able to contain major political divides even in times of extreme polarisation and oppression, largely by silencing them. Such successes are possible in contexts where the participants in a literary circle share enough important common ground to evade political differences. In the Writers' Union, where political differences are carefully and successfully silenced, that common ground includes proximity to state institutions and post-colonial militant nationalism, paths of personal and literary formation in public-sector institutions, and importantly age and generation. The twentieth-century modernist ideal of autonomy and commitment meant that writers commonly saw themselves as a critical, and often also oppositional, power vis-à-vis the government, yet at the same time were committed to the nationalist project of independence and development (Klemm 1998; Jacquemond 2008; Mehrez 2010: 78-82). The Writers' Union stands out as a gathering of people whose lives and fantasies are marked by the Nasserist state and its institutions, even if they may be ideologically pitted against it. Even after the decline of public-sector institutions, it remains embedded in a logic of statist power that in Egypt is referred to as al-mu'assasa, 'the institution'. This institutional sense of home is further enforced by a widely shared

often argued in strikingly similar terms, and have also insisted on the link between liberation and nationalism.

14 Members of the group translated their name as 'case' into English, but meant the condition or state of poetic inspiration. 
moral and societal understanding of literature linked with moral guidance and commitment.

This leads to another important multipolar divide: institutional, generational, and class-based paths of literary formation. Those paths and their corresponding networks of friendship can be more important than aesthetics and politics. A good example is the Writers' Union's active minority of writers who promote more experimental aesthetics, often against sturdy opposition from members with more conservative tastes. They are young enough to have shared in the shift of the literary avant-garde of the 1990s from nationalist commitment towards a focus on ordinary life and the self (and the associated aesthetic shift towards prose poetry), and at the same time old enough to find themselves very much at home in public-sector literary institutions. In contrast, for many young writers from middle-income and bourgeois urban families who have come of age in a time of corrupt economic liberalisation and crumbling state institutions - many of whom gained a formative generational experience in the utopian moment of the 25 January uprising - the public sector no longer provides a self-evident framework for their literary strivings.

This generational shift, generational in the sense of societal cohorts that share a formative experience (Mannheim 1972), coincides with the rise of independent institutions and the proliferation of radical and alternative visions of life in the wake of the 25 January revolution. In consequence, the Writers' Union in particular has become dominated by older writers, and is increasingly disconnected from recent developments in the 'independent scene', while spaces such as Fabrica stood out as extremely youthful - the two founders of the space being almost the only people over thirty whom we met there. The youthfulness of Fabrica was linked with a class-specific socialisation of most of its young participants: they were educated in international and private schools, and many of them were raised in the Gulf where their parents worked.

The generational formation of working careers and social experience is paralleled by generational layers of intertextuality. Regarding Arabic literature from the classics until the end of the twentieth century, there is a largely (albeit not entirely) shared canon, but less so in terms of translated literature and recent Arabic literature. In all literary circles we frequented, world literature featured highly on the lists of authors' influential or favourite reading. Even the most outspoken literary nationalists in the Writers' Union took pride in their knowledge of translated literature and literary theory. They would most likely have read late nineteenth- and early twentieth-century European prose (Russian classics featured prominently, thanks to the outstanding translation work of the Soviet Cultural Centres during the Cold War). Younger writers, in contrast, were influenced by more recent authors of global circulation (Haruki Murakami, Elif Shafak, and 
Orhan Pamuk were among the prominent names mentioned to us in conversations). Only a few translated works were popular across generations, the most important of them being Gabriel García Márquez’s Hundred Years of Solitude (2005).

\section{Milieus at intersection}

The intersections of these lines of division are what we call milieus: the productive coming together of aesthetics, institutions, politics, generations, and class trajectories. The shared formative ideals and experiences of a milieu provide a common ground for communication and mutual recognition. They also produce lines of division against others who can be critiqued and ridiculed for being oldfashioned, vulgar, unpatriotic, immodest, narrow-minded, or otherwise not real literati. In the specific historical circumstances of Alexandria's literary landscape after 2011, the lines of division sketched here merged to produce at least three to four key milieus that we encountered in our fieldwork.

The first milieu we encountered was that of public-sector institutions and authors who were committed to a rather conservative version of twentieth-century modernist aspirations (see Armbrust 1996), expansive in terms of literary aesthetics and politics, and held together by a generational commitment to public-sector institutions along with ideals of authorship that foreground moral guidance and commitment. This milieu continued to recruit younger members, but it was dominated by people past their middle ages. Of the circles mentioned here, the Writers' Union, the Hala literary group, and most gatherings we attended at cultural centres were located in this milieu. It was pluralistic enough to be home to writers with avant-garde aspirations and a critical relationship with state institutions. Mukhtabar al-Sardiyat was open towards this milieu but was not located in it. Instead, it occupied a middle ground between it and two other milieus.

A second milieu was linked with internationally or privately funded cultural institutions, cosmopolitan connectedness, a critical distance from state institutions that often translated into revolutionary politics in the period from 2011 to 2013, avant-garde strivings, and to some degree alternative lifestyles that are in Arabic often brought together in the phrase mustaqill (independent). This milieu was pluralistic in terms of age and generation, but was to some degree classexclusive owing to the bourgeois location of alternative aesthetics. Unlike other milieus, it had a clear geographic location in downtown Alexandria. Of the circles we have mentioned, the group of people involved in al-Kull, El Cabina, and other projects were most clearly located in this milieu, while Fabrica was located in both this milieu as well as the third one we encountered. 
This third milieu, which could also be described as two or more milieus, was linked with private and commercial productions and being able or striving to reach larger audiences. It had a largely friendly relation with public-sector institutions (especially the Alexandria Library), and was aesthetically inclusive and politically ambiguous. In generational terms, it was overwhelmingly youthful. It involved the circulations of various forms of commercial and popular literature, including specific genres such as horror, satire, and colloquial poetry. It was divided in terms of class and distinctiveness into at least two parts. One section had more cosmopolitan aesthetics, alternative lifestyles, and demanding tastes on literature and theory, and had more affinity with the second milieu. Fabrica was located in this, the more highbrow and cosmopolitan part. Another part was characterised by more mainstream or conservative aesthetics, less distinctive lifestyles, and had more affinity with the first milieu. Many of the private cultural spaces that survive in Alexandria mainly cater to the second, commercial-inclusive part, as do many large-audience events at the Alexandria Library.

Literary imagination and literary careers are guided and made possible by intersecting forms of socialisation, shared experiences, and relations of power - or what we call the milieu. In our ethnography, key formative contexts have been aesthetics and intertextuality, friendship and conflicts, class, urban landscape, religion, gender, and shared generational experiences. Through them - and against them - writers develop their specific literary voice and author persona. The power of such milieus is fourfold. First, they encourage and make possible certain expressions, aesthetics, and ways of relating to society and state. Second, they restrict movement beyond their productive limits. Third, they divide the literary landscape into specific scenes and circles that emerge as the result of political, aesthetic, generational, institutional, and personal differences. Fourth, by providing divisive lines of exclusion and distinction, they also encourage the crafting and cultivation of specific styles and traditions of living and writing that are marked by both what they are and what they are not.

It is important to remember, though, that these are intersections, not bounded entities. Individual literary careers often involve shifting trajectories through scenes and milieus. They often involve periods of movement at the margins, as a visitor rather than a convenor of literary life, searching and experimenting with aesthetic and techniques, as well as periods in which authors with sufficient success and name settle at the centre of a space or a network, and develop or build on an acquired style of writing. Metaphorically speaking, writers can join the nucleus of a literary circle on some occasions, and on other occasions act as electrons, orbiting and travelling between literary circles, attracted and repelled by them, and affecting them by their entrance and departure (Shehata 2020). This oscillation between roles and positionalities is not unlimited of course, for the 
formation of writers in specific circles and milieus also structures their possible next steps. But it does give literary lives and milieus a more dynamic and unpredictable nature.

One example of such an oscillation is Alshimaa Hamed's trajectory across various circles to eventually become a central figure in a circle of her own for a few years, only to move on to another city and art form afterwards. Another example is the shift in Abdelrehim Youssef's attendance of literary events after 2016, from being a main organiser of events at El Cabina and almost constantly present at the venue, to being a freelance translator with no institution to run, who could therefore begin attending various literary gatherings out of curiosity, including those that he found aesthetically not to his taste but otherwise enjoyable. A third example is of Abdelrehim and Alshimaa, who both frequented the Asil group in around 2000 as new authors, where the much more senior writer Abdelfatah Morsi (whom we introduce in Chapter 3) was a frequent participant. During our fieldwork, Abdelfatah Morsi was active in a literary milieu that had little or no contact with the milieu Abdelrehim and Alshimaa were involved in; and yet they had once been part of the same circle and scene.

\section{Openings and closures}

A duality of inclusion and exclusion appears to be inherent to literary milieus. But different milieus have specific and different aspects of openness and closure, which have emerged in a specific historical configuration. The more at variance with the societal mainstream and with conservative values and aesthetics a literary milieu is, the more it needs social closure to survive. The more open and accessible towards various social milieus a literary milieu is, the more it needs institutional, aesthetic, or moral closure to be accepted. One form of closure appears to be a near universal feature, however: that against competing writers and circles.

All literary circles we attended were busy with distinguishing themselves from others. Competition and conflicts within circles were equally common, and often resulted in splits and the formation of new circles. Writing is grounded in sociality, but authorship is egocentric. Literary circles are often highly personcentred, and they come together and fall apart through relations of friendship and patronage, conflict and competition. Aesthetic, political, and personal dimensions of competition and conflicts are therefore often inseparable.

Not all rants and rivalry are about direct competition. Book fairs are among the few occasions when people with different literary tastes are likely to encoun- 
ter each others' works, and they are therefore also annual occasions to mark the lines of one's literary taste by ridiculing others. The Cairo International Book Fair is regularly accompanied by viral photos on social media showing passages of poetry considered ridiculously bad or scandalously embarrassing in the view of those who circulate them. Works that gain such unfavourable attention are often first publications by young female authors who are to some degree outsiders to literary milieus. The ridicule of new writers at the book fair typically takes aim at those who lack experience and power and are therefore weak and easy targets for a collective hafla (literally 'party') or online shitstorm. Such collective ridicule allows those who participate in it to confirm their own sense of commanding good taste, at the expense of others with whom they are not in direct competition and who therefore cannot fight back.

Public ridicule can be extremely painful and damaging for the individuals exposed to it. However, it also keeps milieus and scenes intact by marking their aesthetic boundaries. Internal conflicts within milieus, in contrast, can result in collective splits as well as personal pain. In 2016, the downtown milieu around independent institutions was involved in one such internal conflict. A young playwright published a social media post in which he objected to the fact that an intellectual debate at an international cultural institute in Alexandria was going to be held in English although all participants knew Arabic. Both sides of the debate had their arguments (interestingly, both considered their preferred language to be more inclusive), but very soon arguments became irrelevant. Within a day and a night, the debate escalated into an increasingly confrontational hafla with ever more people involved, and accusations against the organiser of the event turned increasingly personal. The debate might have resulted in permanent damage, and certain people might have stopped talking to each other, had it not been for the intervention by K., who was well connected with people on both sides of the debate. We happened to be in a café listening to the point of view of someone who was vocally criticising the organiser of the event, when he received a phone call from K. - who was concerned because the debate was turning personal. He promised her he would tone down his remarks. The next day, all parties in the previous day's debate attended the event. This also showed courtesy towards the organiser, who was predictably distressed about the way the theme he had wanted to discuss had been sidetracked by the debate about language.

Conflicts thus appear at their fiercest within milieus - or at least this was the case in the 2010s, when different milieus drew on largely separate material resources and means of symbolic capital. With the distance between writers in terms of milieus increasing and the shared ground of readership, recognition, and resources decreasing, the heat of such conflicts decreases. Fierce enmity softens to annoyed ranting, and ranting to ridicule and joking. Although this can 
still be extremely damaging towards those who are exposed to it publicly, from the point of view of those who engage in such ranting and ridicule, it implies a safer distance. This is not an entirely predictable process, however, because personal relations are so important. Just as people with otherwise similar literary tastes may fiercely reject each other's work for reasons of personal rivalry, they may also form alliances and support work that is quite different from theirs if they are connected by ties of friendship or patronage.

When we add the unpredictable and often destructive process of conflicts and competition to the movement of individuals between circles and a productive dialectic between openness and closure, the outcome is a landscape that is in constant transformation. New splits and new networks continue to emerge at an often rapid pace, and over longer periods, new institutions and generations gain shape. A question that remains is to what degree such fragmentary tendency is a constant feature of literature as a social institution, or whether it has increased.

The demise of literary groups with an explicit collective identity provides clues to the answer to this question. Richard Jacquemond (2008: 168-171) argues that between the 1960s and 1990s, literary groups formed as attempts by usually young authors to claim a space and a name for their writings against a preceding generation, and typically split when some of their members became successful enough to claim a name for themselves individually. They are thus both coherent and fragile. In the 2000s, literary groups came into fashion once more, according to Abdelrehim Youssef (in conversation with Samuli in 2019), partly aided by Egyptian literary journalists who were interested in covering them. But they went out of fashion almost overnight with the outbreak of the 25 January revolution. Throughout the 2010s, Alexandria had only one prominent and consistently active literary group, Itlala.

Since approximately 2011, at least three developments have made such collective identities less appealing. One important development is the movement of much of literary commentary and debate to online spaces, Facebook and Goodreads being the two most prominent platforms during the time of our fieldwork. Online sociality generates a less personal form of group coherence. Online encounters allow for a less intimate and personal engagement, while at the same time the architecture of online groups allows administrators to maintain coherence by single-handedly blocking members whose input they find disagreeable (Elsherif forthcoming). This development is paralleled by a general tendency towards the fragmentation of social life, lifestyles, and attitudes that was further amplified by the revolution. Authors of a younger generation appear to find somewhat less appeal in identifying with a group. Another important development has been the proliferation of new forms of offline literary sociality in dedicated cultural spaces and writing workshops (which we address in Chapter 
3). The emerging culture of workshop learning in combination with easy private publishing has contributed to a shortening of the ustaziya (master-apprentice) relations with key senior writers who support and promote young writers joining the scene. In consequence, young authors may claim an independent stance at an earlier stage. All these developments are marked by a lower degree of coherence and group continuity, and a higher degree of fluctuation and individuality.

This shift is only gradual, however. The circle of friends that focused on key persons and shared projects in the 2000s that for a while became known as the al-Kull literary group still exists and remains active at the time of writing (2020), albeit without a trademark identity and with a partially different cast (some people have left the circle owing to conflicts or personal circumstances, and new ones have joined). New networks of writers without a collective identity continue to emerge from successful programmes such as Alshimaa Hamed's writing workshops in 2011-2015 (which we describe in Chapter 3) and Mounir Oteiba's Mukhtabar al-Sardiyat. Developing a literary style and approach, and gaining feedback, support, resources, and recognition are and remain fundamentally social affairs; and for all those writers whose readership is small (that is, almost all of them), the sociality of symposiums, coffee house gatherings, and online platforms is indispensable, as is the reliance on ustaziya relationships. Such sociality generally thrives on a degree of closure, exclusivity, and marginality, which is why in Chapter 3 we turn our focus to the productive shared margins that enable some people to engage in literary writing as a life-shaping practice. 